\title{
Digestive Physiology of Steers Grazing Fertilized and Non- fertilized Blue Grama Rangeland
}

\author{
L.J. KRYSL, M.L. GALYEAN, M.B. JUDKINS, M.E. BRANINE, AND R.E. ESTELL
}

\section{Abstract}

Eight neld trials [early August 1983 (EAUG83), late August 1983 (LAUG83), early November 1983 (ENOV83), early January 1984 (EJAN84), May 1984 (MAY84), late July 1984 (LJUL84), late August 1984 (LAU G84), late November 1984(LNOV84)] were conducted on blue grama (Bouteloua gracilis) rangeland in southern rangeland in southern New Mexico to examine relationships among nitrogen (N) fertilization of forage, stage of plant growth, diet botanical and chemical composition, forage intake, digesta kinetics, and ruminal fermentation in beef steers. A fertilized pasture (45 kg N/ha) was evaluated during the year of and year after fertilizer application and compared with an adjacent nonfertilized pasture. Two esophageal- and 4 ruminally cannulated steers/pasture were used in a split-plot design. Dietary organic matter percentage was not affected by fertilization; however, fiber components increased as plants approached dormancy on both fertilized and nonfertilized rangeland. Dietary crude protein levels were numerically higher in the fertilized pasture within all trials. Fertilization had no consistent effect on rate or extent of in vitro orzanic matter digestibility. Fertilization inereased $(P<0.05)$ ruminal ammonia ( $\mathrm{NH}_{3}$ ) concentrations in all but one trial and levels were adequate for maximal microbial protein synthesis; however in the nonfertilized pasture, ruminal $\mathrm{NH}_{3}$ levels were potentially inadequate during periods of dormancy. Ruminal pH was numerically higher for steers on the fertilized pasture than for those on the unfertilized pasture each sampling trial except LNOV84. Fertilization had little effeet $(P>0.05)$ on total volatile fatty acid (VFA) concentration or molar proportion of individual acids. Total ruminal VFA concentration was highest in steers during periods of active plant growth. Voluntary organic matter intake was usually unaffected $(P>0.05)$ by fertilization except in EJAN 84 when intake was higher $(\boldsymbol{P}<0.05)$ in the fertilized pasture and LNOV84 when intake was higher $(P<0.05)$ for steers grazing the nonfertilized pasture. Organic matter intake by steers averaged $21.8 \mathrm{~g} / \mathrm{kg}$ body weight (BW) and $21.6 \mathrm{~g} / \mathrm{kg} \mathrm{BW}$ across the 8 trials for fertilized and nonfertilized pastures, respectively. Intake in both pastures declined with advancing season. Particulate passage rate (PPR) was not different between treatments $(P>0.05)$ during ENOV83, MAY84 and LNOV84. However, PPR was faster $(P<0.05)$ for steers grazing the fertilized than in the nonfertilized pasture during the remaining 5 sampling periods. Correspondingly, retention time of digesta in the gastrointestinal tract was reduced for steers grazing the fertilized pasture during these 5 trials. Estimated gastrointestinal fill was unaffected $(P>0.05)$ by treatment except during the EAUG83 and LAUG84 trials when steers grazing fertilined pasture had reduced $(P<0.05)$ fill compared with steers grazing nonfertilized pasture. Fluid passage rate (FPR) did not differ $(P>0.05)$ between treatments for any trials except in LAUG84 when steers in the fertilized pasture had a lower $(P<0.05)$ FPR than steers in the nonfertilized pasture.

\section{Key Words: forage quality, fertilization, dizesta kinetics}

\footnotetext{
At the time of this research, authors were graduate assistant, associate professor and graduate assistants respectively, Department of Animal and Range Sciences, New Mexico State University, Las Cruces 88003. Krysl is currently assistant professor, Department of Animal Science, University of Nevada-Reno. The authors wish to acknowledge the assistance of Drs. J.D. Wallace, G.B. Donart, R.D. Pieper, and Mr. E.E. Parker.

Journal article No. 1211 of the New Mexico Agr. Exp. Sta., Las Cruces.

Manuscript accepted 2 June 1987.
}

Livestock production from native rangeland depends on diet quality and availability. Various improvement practices and landuse strategies have been implemented in an attempt to manipulate vegetative resources to maximize animal production.

Fertilization of rangeland has been employed to increase forage quantity and quality and consequently, animal production. Humphrey (1960) indicated range forage production was limited more by nitrogen $(\mathrm{N})$ deficiency than by any other element. Nitrogen fertilization has increased herbage production on native rangeland (Rogler and Lorenz 1965, Burzlaff et al. 1968, Goetz 1969). Under proper conditions, $\mathbf{N}$ fertilization of blue grama (Bouteloua gracilis) dominated rangeland has resulted in a several-fold increase in annual herbage production (Banner 1969, Reed 1969, Schickedanz 1970, Kelsey et al. 1973, Pieper et al. 1974, Donart et al. 1978). Furthermore, diet quality (Kelsey et al. 1972, 1973; Havstad et al. 1979; Wallace et al. 1983) and animal production (Schickedanz 1970; Donart et al. 1978, 1983) have been enhanced by $N$ fertilization of blue grama rangeland.

Another important consideration regarding livestock production on native rangeland is the influence of advancing season on decline of nutritive value and diet selection of grazing ruminants. Such information is paramount to development and implementation of grazing schemes and supplementation programs. Several authors (Cook 1972, Pieper et al. 1978, Kothmann 1980, McCollum et al. 1985) have examined the influence of advancing season on nutritive value of range forages; however, few studies (McCollum et al. 1985) have related diet quality to ruminal characteristics of the grazing herbivore. Because the rumen is the primary site of forage degradation, ruminal fermentation end-products and $\mathrm{pH}$ of ruminal contents may have profound effects on fiber digestion (Mertens 1979), microbial protein synthesis (Satter and Slyter 1974), and ultimately energy and protein available for maintenance, growth, and reproduction of grazing animals.

To improve forage utilization and productivity from native rangelands, it is necessary to measure or at least approximate components that affect livestock production. Forage intake by the grazing ruminant may be the most important of these components. It is essential that factors regulating forage intake be understood in order for livestock managers to make responsible management decisions to enhance livestock productivity and profitability.

Cordova et al. (1983) reviewed literature on intake of grazing sheep and cattle and found values ranging from 1 to $2.8 \%$ of body weight. Other researchers have examined effects of advancing season on quality and intake of legumes forages (Van Soest 1965, Thornton and Minson 1973). Only limited information is available on chemical and botanical composition of the diets of freely grazing ruminants and associated changes in forage intake (Holechek and Vavra 1982, McCollum and Galyean 1985b).

Rate of digesta disappearance from the gastrointestinal tract of ruminants encompasses both rate of digestion and rate of passage of undigested residues (Ellis 1978, Van Soest 1982). Furthermore, Ellis (1978) concluded ruminal volume, volume occupied by undigested residues and factors influencing ruminal turnover were the major determinants of forage intake. Hence, studies examining the interrelationships of these factors in grazing ruminants should provide greater insight into possible mechanisms controlling forage intake.

Cognizant of these potential relationships, we undertook this 
study to relate dietary changes in steers grazing $\mathbf{N}$ fertilized and nonfertilized blue grama rangeland during the year of and year after fertilization with changes in seasonal forage quality, ruminal fermentation, intake, and digesta kinetics.

\section{Materials and Methods}

\section{Study Area}

Field data for this study were collected at the Fort Stanton Experimental Ranch located in the foothill-mountain region between the Sierra Blanca and Capitan Mountains in southern Lincoln County, New Mexico. Elevation of the area is variable, ranging from 1,900 to $2,300 \mathrm{~m}$, with the study pastures at $1,950 \mathrm{~m}$. Mean temperature is $11^{\circ} \mathrm{C}$, with a mean maximum of $18.6^{\circ} \mathrm{C}$ and a mean minimum of $2.2^{\circ} \mathrm{C}$. The average frost-free period is 161 days, with average first frost date of 10 October and average last frost date of 2 May. Mean annual precipitation is $35 \mathrm{~cm}$ with approximately $65 \%$ of the precipitation occurring between midJuly and late-September, which coincides with the growing season of the major forage species in the region (Pieper et al. 1971).

The study area was a 117-ha pasture fenced into 2 paddocks which were similar in terms of topography and vegetation. One pasture (56-ha) was fertilized biennially (single application) with 45 $\mathrm{kg}$ actual $\mathrm{N} / \mathrm{ha}$ (dry urea) just before the growing season. During the present study, fertilization occurred 18 June 1984.

Historically, a biennial fertilization scheme was implemented in 1979. The pasture was fertilized annually from 1968 to 1979.

The pastures were similar in vegetative composition (Wallace et al. 1983). Vegetation is dominated by an overstory of pinyon pine (Pinus edulis) and various juniper species (Juniperus spp.). Major understory grasses are blue grama, sideoats grama (Bouteloua curtipendula), hairy grama (B. hirsuta), sand dropseed (Sporobolus cryptandrus), mat muhly (Muhlenbergia richardsonii), ring muhly (M. torreyi), wolftail (Lycurus phleoides), western wheatgrass (Agropyron smithi), and various panic grasses (Panicum spp.). Important forbs and shrubs are carruth sageworth (Artemisia carruthi), scarlet globemallow (Sphaeralcea coccinea), Dakota verbena (Verbena bipinnetifida), nuttall milkvetch (Astragulas nuttallianus), buckwheat (Eriogonum spp.), fendler bladderpod (Lesquerella fendleri), kochia (Kochia scoparia), portulaca (Portulaca pilosa), sandlily (Mentzelia humilis), plains zinnia (Zinnia grandiflora), broom snakeweed (Xanthocephalum sarothrae) and yucca (Yucca elata; Lebgue and Allred 1985).

\section{Field Trials}

Eight trials were conducted in 1983 and 1984 [early August 1983 (EAUG83), late August 1983 (LAUG83), early November 1983 (ENOV83), early January 1984 (EJAN84), May 1984 (MAY84), late July 1984 (LJUL84), late August 1984 (LAUG84), late November 1984 (LNOV84)]. These sampling times were chosen to observe the effect of $\mathbf{N}$ fertilization over a broad range of plant maturity.

During each trial, 2 esophageal-cannulated steers-pasture and 4 ruminally-cannulated $(10.2 \mathrm{~cm}$ id cannula) steers/pasture were allowed to freely graze study pastures. A salt-mineral mix (50\% dicalcium phosphate, $45 \%$ salt and $5 \%$ cottonseed meal) was provided free choice in each pasture. Esophageal-cannulated steers were placed on pasture a minimum of 1 wk before each trial, while ruminally-cannulated steers were allowed a 2 -wk minimum adaptation period.

Diet samples were collected 3 times during the first $2 \mathrm{~d}$ of each 9-d trial. The 2 esophageal fistulated-steers in each pasture were located during pre-dawn $(0600-0700 \mathrm{~h})$ and pre-sunset $(1900-2000$ h) periods. Once located, steers were bagged and allowed to graze for 30-45 minutes. Steers were not denied feed or water before collections. Following collection, $20 \%$ aliquot of each extrusa sample was placed in a plastic bag and stored frozen for future botanical and nutrient analyses. Remaining masticate was composited by treatment, labeled with ytterbium (Yb) for determination of particulate passage rate and fecal output. Labeling procedures have been described in detail by Teeter et al. (1984) and McCollum and Galyean (1985a). Briefly, composite masticate samples were washed to remove salivary contaminants and soaked for $24 \mathrm{~h}$ in an aqueous solution containing $2.5 \mathrm{~g} \mathrm{YbCl}_{3} \bullet \mathrm{XH}_{2} \mathrm{O} /$ liter. After soaking, excess fluid was poured off and the remaining sample was washed with deionized water hourly for $6 \mathrm{~h}$ to remove unbound $\mathrm{Yb}$. Labeled forage was divided into equal portions with 1 aliquot/treatment removed from $\mathrm{Yb}$ dose determinations.

Rumen fluid samples from 4 steers in each pasture were collected the third day of each trial. At sunrise $(0600-0800 \mathrm{~h})$, a $250-\mathrm{ml}$ sample of whole ruminal contents was withdrawn after thoroughly

Table 1. Botanical and nutritional compoaition of steer diets from fertilized (F) and nonfertilized (NF) blue grama rangeland during the year of and after fertilization.1

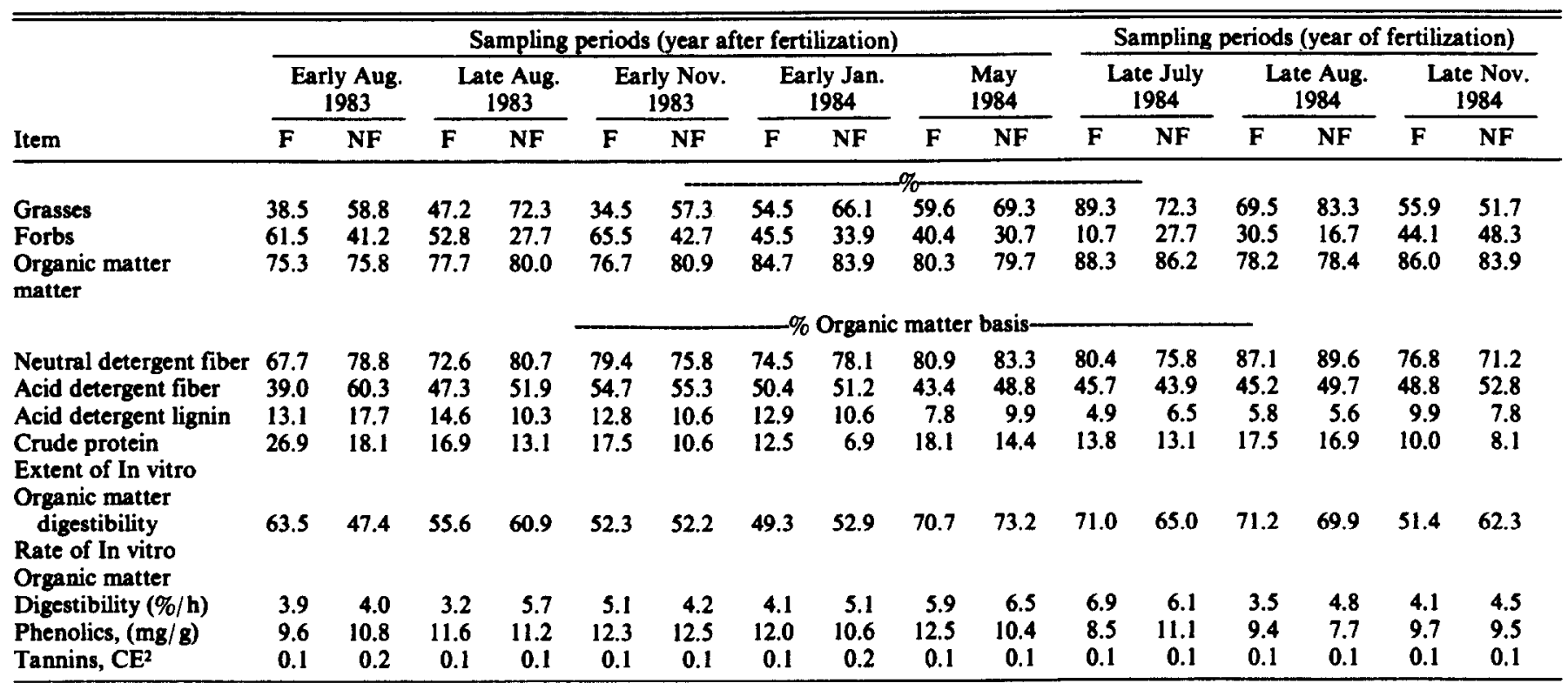

INo statistical analyses was conducted on these data.

'Catechin equivalents 
Table 2. Ruminal fermentation measurements in teers graxing fertlized (F) and nonfertillzed (NF) blue grama rangeland the year of and year after fertillzation.

\begin{tabular}{|c|c|c|c|c|c|c|c|c|c|c|c|c|c|c|c|c|c|c|c|c|c|c|c|c|}
\hline \multirow[b]{3}{*}{ Item } & \multicolumn{15}{|c|}{ Sampling periods (year after fertilization) } & \multicolumn{9}{|c|}{ Sampling periods (year of fertilization) } \\
\hline & \multicolumn{3}{|c|}{$\begin{array}{c}\text { Early August } \\
1983 \\
\end{array}$} & \multicolumn{3}{|c|}{$\begin{array}{c}\text { Late August } \\
1983 \\
\end{array}$} & \multicolumn{3}{|c|}{$\begin{array}{c}\text { Early November } \\
1983 \\
\end{array}$} & \multicolumn{3}{|c|}{$\begin{array}{c}\begin{array}{c}\text { Early January } \\
1984\end{array} \\
\end{array}$} & \multicolumn{3}{|c|}{$\begin{array}{l}\text { May } \\
1984 \\
\end{array}$} & \multicolumn{3}{|c|}{$\begin{array}{c}\text { Late July } \\
1984\end{array}$} & \multicolumn{3}{|c|}{$\begin{array}{c}\text { Late August } \\
1984 \\
\end{array}$} & \multicolumn{3}{|c|}{$\begin{array}{c}\text { Late November } \\
1984 \\
\end{array}$} \\
\hline & $\mathbf{F}$ & NF & $\overline{\mathbf{S E}} \mathbf{E}^{*}$ & $\mathbf{F}$ & NF & $\overline{\mathrm{SE}}$ & $\mathbf{F}$ & NF & $\overline{\mathbf{S E}}$ & $\mathbf{F}$ & NF & $\mathbf{S E}$ & $\mathbf{F}$ & NF & SE & $\mathbf{F}$ & NF & $\mathbf{S E}$ & $\mathbf{F}$ & NF & SE & $\mathbf{F}$ & NF & SE \\
\hline & 6.3 & 6.2 & 0.1 & $6.5^{b}$ & $6.1^{\mathrm{c}}$ & 0.1 & $6.5^{b}$ & $6.0^{c}$ & 0.1 & 6.5 & 6.4 & 0.1 & 6.1 & 5.9 & 0.1 & 6.2 & 5.9 & 0.1 & $6.4^{\mathrm{b}}$ & $6.0^{c}$ & 0.1 & 6.1 & 6.3 & 0.1 \\
\hline $\begin{array}{l}\text { Ammonia- } \\
\mathrm{N} \\
(\mathrm{mg} / 100 \mathrm{ml})\end{array}$ & $14.9^{b}$ & $9.2^{\circ}$ & & $11.2^{b}$ & $5.5^{\mathrm{c}}$ & 0.7 & $6.2^{b}$ & $2.2^{c}$ & 0.4 & $5.3^{b}$ & $3.2^{c}$ & 0.5 & $13.9^{\mathrm{b}}$ & $7.8^{\mathrm{c}}$ & 1.0 & $10.3^{b}$ & $7.6^{\mathrm{c}}$ & 0.3 & $19.6^{\mathrm{b}}$ & $12.6^{\mathrm{c}}$ & 1.0 & $5.8^{b}$ & $3.0^{c}$ & 0.9 \\
\hline $\begin{array}{l}\text { Total } \\
\text { VFA, } \mathrm{mM}\end{array}$ & 102.0 & 103.7 & 4.2 & 91.9 & 96.0 & 2.0 & 85.1 & 81.8 & 2.9 & 80.4 & 78.7 & 2.4 & 89.9 & 88.4 & 4.5 & 65.6 & 68.9 & 2.8 & 64.5 & 62.3 & 2.8 & 74.4 & 72.6 & 7.2 \\
\hline & & & & $8^{\mathrm{b}}$ & & & & & & & 5.5 & 16 & & 53 & 6 & 7.6 & 68.9 & 0.6 & 4.5 & 62.3 & 2.0 & 74.4 & 72.6 & 0.7 \\
\hline nate & 18.0 & 18.7 & 0.3 & 17.2 & 16.7 & 0.4 & 17.7 & 17.7 & 0.7 & 18.4 & 17.4 & $\begin{array}{l}0.0 \\
0.5\end{array}$ & 19.2 & 18.4 & 0.5 & 18.6 & 17.6 & 0.5 & 18.9 & 18.3 & 0.5 & 16.2 & 10.4 & 0.2 \\
\hline Butyrate & 11.5 & 12.4 & 0.4 & 9.4 & 9.9 & 0.5 & 9.0 & 8.9 & 0.5 & 7.2 & 7.0 & 0.3 & 10.5 & 12.0 & 0.6 & 10.2 & 10.6 & 0.3 & 12.0 & 16.0 & 2.2 & 8.0 & 8.7 & 0.2 \\
\hline & $4.8^{b}$ & $3.6^{\mathrm{c}}$ & 0.2 & $4.6^{b}$ & $3.1^{c}$ & 0.2 & 0.4 & 0.1 & 0.1 & $1.0^{\mathrm{b}}$ & $0.1^{c}$ & 0.2 & 3.8 & 3.3 & 0.1 & $3.6^{\mathrm{b}}$ & $2.9^{c}$ & 0.1 & $4.6^{\mathrm{b}}$ & $3.4^{\mathrm{c}}$ & 0.2 & $1.4^{\mathrm{b}}$ & $2.3^{c}$ & 0.2 \\
\hline
\end{tabular}

Standard error, $n=16$

be Means within trials differ

${ }^{\mathrm{d}}$ Minor acids $=$ isobutyrate + valerate + isovalerate

hand-mixing contents. Ruminal pH was measured immediately with a combination electrode, after which samples were strained through 8 layers of cheesecloth, acidified $\left(1 \mathrm{ml} 7.2 \mathrm{~N} \mathrm{H}_{2} \mathrm{SO}_{4} / 100 \mathrm{ml}\right.$ strained fluid) and frozen. After initial sampling, each steer was dosed intraruminally with $200 \mathrm{ml}$ of cobalt ethylenediaminetetraacetic acid solution (CoEDTA; Uden et al. 1980) as a fluid passage marker. Steers were allowed to return to normal grazing activities and additional 250-ml digesta samples were obtained at 4, 8, 12, and $24 \mathrm{~h}$ postdosing.

On day 4 of each trial at sunrise $(0600-0800 \mathrm{~h})$, each ruminally cannulated steer was dosed intraruminally with its respective portion of Yb-labeled masticate. Dose was placed in the middorsal region of the rumen. Because of variation in amount of masticate collected and $\mathrm{Yb}$ binding efficiency, the amount of forage and $\mathrm{Yb}$ administered varied among trials. In EAUG83, LAUG83, LNOV83, LJAN84, MAY84, LJUL84, LAUG84 and ENOV84, steers grazing fertilized pasture were dosed with $3.2,2.5,2.6,2.6,2.1,2.1,2.6$, and $3.0 \mathrm{~g} \mathrm{Yb}$, respectively. Steers grazing nonfertilized pasture were dosed with $2.0,2.3,2.4,2.6,2.5,2.7,2.0$ and $2.5 \mathrm{~g} \mathrm{Yb}$ for the respective dates mentioned above. After dosing, steers were allowed to resume normal grazing activity and rectal grab samples were collected at $0,4,8,12,16,20,24,28,32,36,42,48,54,60,72$, $84,96,108$, and $120 \mathrm{~h}$ postdosing. Individual grab samples were identified by steer and collection time and frozen.

\section{Laboratory Analyses}

Botanical composition of diets was determined using procedures outlined by Sparks and Malechek (1968). Four slides of each esophageal sample were mounted and examined at $100 \times$ magnification until 15 fields/slide were viewed. Dietary similarities between pastures were calculated using Kulczynski's similarity index (Oosting 1956).

Esophageal samples were dried at $50^{\circ} \mathrm{C}$ for $48 \mathrm{~h}$ and ground through a $2-\mathrm{mm}$ screen in a Wiley mill. Dry matter and ash content were determined by standard procedures (AOAC 1984). Dietary fiber constituents [acid detergent fiber (ADF), acid detergent lignin (ADL), neutral detergent fiber (NDF)] were determined according to Goering and Van Soest (1970). Kjeldahl procedures were used for $\mathrm{N}$ analyses (AOAC 1984).

In vitro organic matter disappearance determination was conducted on the fourth day of the field trial, using esophageal extrusa samples composited across steers (within pasture) and sampling days as a substrate. Extrusa was dried at $50^{\circ} \mathrm{C}$ for $48 \mathrm{~h}$ and ground through a 2-mm screen in a Wiley mill. Ruminal fluid inocula were collected at sunrise (0600-0800 h) from ruminally cannulated steers grazing study pastures during each trial. Ruminal fluid from 2 steers (randomly paired within a pasture) were composited for the other replication. This compositing scheme was repeated in the adjacent pasture. Extent of in vitro organic matter disappearance (IVOMD) was estimated using the Tilley and Terry (1963) 2-stage technique $(48 \mathrm{~h}$ rumen fluid, $48 \mathrm{~h}$ pepsin digestion on $0.5 \mathrm{~g}$ samples in triplicate). Rate of organic matter disappearance $\left(k_{d}\right)$ was calculated using methodology described by Mertens and Loften (1980). Incubation times used for rate analysis were $0,4,8,12,16,20,24$, $30,36,48$, and $72 \mathrm{~h}$.

Condensed tannins were determined on esophageal masticate samples using the vanillin- $\mathrm{HCl}$ procedure (Burns 1971) as modified by Price et al. (1978) in which $0.5 \mathrm{~g}$ samples were extracted with $1 \% \mathrm{HCl}$ in methanol for $20 \mathrm{~min}$ by manual inversion. Catechin (flavonoid structurally similar to flavonoids in condensed tannins) was used as a standard in this procedure; thus, results were expressed as catechin equivalents. Total phenolic content of esophageal samples was determined by the Folin-Denis procedure (AOAC 1984). The 24-h extraction with $1 \% \mathrm{HCl}$ in methanol was conducted with $0.5-\mathrm{g}$ samples in a mechanical shaker with continuous shaking.

Ruminal fluid samples were thawed and $40 \mathrm{ml}$ of fluid from each sample was centrifuged at $12,000 \times g$ for $10 \mathrm{~min}$. The supernatant fraction was decanted and an aliquot was analyzed for ammonia concentration by the phenol-hypochlorite procedure of Broderick and Kang (1980). Another aliquot was analyzed for volatile fatty acids by gas chromatography (2-ethylbutyric acid as an internal standard) as described by Goetsch and Galyean (1983). Only ruminal samples collected at $0,4,8$, and 12 h were analyzed for $\mathrm{pH}$, ammonia, and total volatile fatty acids. An additional aliquot was analyzed for cobalt concentration by atomic absorption spectroscopy using an air/acetylene flame.

Fecal samples were prepared for analysis by boiling ash residues in 3.1 N HCL for 30 minutes. After filtration (Whatman 541) and dilution, the solution was analyzed for $\mathrm{Yb}$ content by atomic absorption spectroscopy with a nitrous oxide/acetylene flame. Standards were made in solubilized ash from $0 \mathrm{~h}$ collections, and all samples and standards contained $2,000 \mu / \mathrm{ml}$ of potassium as an ionization buffer.

\section{Calculations and Statiatical Analysis}

Fluid passage rate was calculated by regressing the natural logarithm of Co concentration on time postdosing. Fluid volume was 
Table 3. Orzanic matter and neutral detergent fiber intake, dry matter fill and fecal output in ateers grazing fertilized (F) and nonfertilized (NF) blue grama rangeland during the year of and year after fertilization.

\begin{tabular}{|c|c|c|c|c|c|c|c|c|c|c|c|c|c|c|c|c|c|c|c|c|c|c|c|c|}
\hline \multirow[b]{3}{*}{ Item } & \multicolumn{15}{|c|}{ Sampling periods (year after fertilization) } & \multicolumn{9}{|c|}{ Sampling periods (year of fertilization) } \\
\hline & \multicolumn{3}{|c|}{$\begin{array}{c}\text { Early August } \\
1983 \\
\end{array}$} & \multicolumn{3}{|c|}{$\begin{array}{c}\text { Late August } \\
1983\end{array}$} & \multicolumn{3}{|c|}{$\begin{array}{c}\text { Early November } \\
1983\end{array}$} & \multicolumn{3}{|c|}{$\begin{array}{c}\text { Early January } \\
1984\end{array}$} & \multicolumn{3}{|c|}{$\begin{array}{l}\text { May } \\
1984\end{array}$} & \multicolumn{3}{|c|}{$\begin{array}{l}\text { Late July } \\
1984\end{array}$} & \multicolumn{3}{|c|}{$\begin{array}{c}\text { Late August } \\
1984\end{array}$} & \multicolumn{3}{|c|}{$\begin{array}{c}\text { Late November } \\
1984\end{array}$} \\
\hline & $\mathbf{F}$ & NF & $\mathbf{S E}^{\mathbf{*}}$ & $F$ & NF & SE & $\mathbf{F}$ & NF & SE : & $\mathbf{F}$ & NF & SE & $\mathbf{F}$ & NF & SE & $\mathbf{F}$ & NF & SE & $\mathbf{F}$ & NF & SE: & $\mathbf{F}$ & NF & SE \\
\hline $\begin{array}{l}\text { Steer } \\
\text { weight, kg } 3\end{array}$ & 374.0 & 385.0 & & 392.0 & 413.0 & & 396.0 & 411.0 & & 433.0 & 425. & & 471.0 & 505.0 & & 512.0 & 541.0 & & 561.0 & 590.0 & & 585.0 & 620.0 & \\
\hline $\begin{array}{l}\text { Organic } \\
\text { matter } \\
\text { intake, } \\
\mathbf{g} / \mathbf{k g} / \\
\mathrm{BW}\end{array}$ & 23.0 & 23.6 & 1.5 & 22.9 & 25.6 & 1.5 & 18.9 & 19.2 & $\begin{array}{ll}2 & 0.8\end{array}$ & $21.6^{b}$ & $19.1^{\circ}$ & c 0.7 & 26.1 & 24.5 & 1.0 & 24.8 & 21.4 & 1.6 & 21.9 & 20.0 & 0.7 & $15.5^{\mathrm{b}}$ & $19.6^{\mathrm{c}}$ & 0.9 \\
\hline $\begin{array}{l}\text { Neutral } \\
\text { detergent } \\
\text { fiber intake, } \\
\mathbf{g} / \mathbf{k g ~ B W}\end{array}$ & 15.6 & 18.6 & 1.1 & $16.6^{b}$ & $20.6^{c}$ & 1.2 & 14.4 & 14.5 & 0.6 & 16.1 & 14.9 & 0.5 & 21.1 & 20.4 & 0.8 & $19.9^{b}$ & $16.2^{\mathrm{c}}$ & 1.3 & 19.1 & 17.9 & 0.6 & $11.9^{b}$ & $14.0^{c}$ & 0.7 \\
\hline $\begin{array}{l}\text { Estimated } \\
\text { dry matter } \\
\text { fill, } \mathbf{g} / \mathbf{k g} \\
\mathrm{BW}\end{array}$ & $11.6^{\mathrm{b}}$ & $23.6^{c}$ & 1.8 & 14.2 & 18.6 & 2.0 & 16.4 & 16.0 & 1.0 & 22.6 & 21.4 & 1.1 & 12.0 & 12.5 & 1.1 & 13.5 & 14.5 & 1.3 & $8.6^{b}$ & $14.0^{\mathrm{c}}$ & 1.0 & 16.5 & 17.3 & 1.3 \\
\hline $\begin{array}{l}\text { Fecal out- } \\
\text { put, g/kg } \\
\text { BW }\end{array}$ & $8.4^{b}$ & $12.4^{c}$ & 0.7 & 10.2 & 10.0 & 0.6 & 8.7 & 9.1 & 0.4 & $11.0^{\mathrm{b}}$ & $9.0^{\circ}$ & $c^{c} 0.3$ & $7.6^{b}$ & $6.6^{\mathrm{c}}$ & 0.2 & 7.0 & 7.3 & 0.5 & $5.6^{\mathrm{b}}$ & $6.3^{c}$ & 0.2 & 7.1 & 7.40 & 0.4 \\
\hline
\end{tabular}

Standard error, $N=4$
beans within trials differ $(P<0.05)$

estimated by dividing dose by estimated concentration at $0 \mathrm{~h}$. Fecal $\mathrm{Yb}$ excretion curves were analyzed by nonlinear regression procedures (Marquardt method) of the Statistical Analysis System (SAS 1984) using a 1-compartment model (Pond et al. 1982): $Y=k_{0}$ - $(t-t a u) \cdot\left(k_{1}{ }^{2}\right) \bullet e^{-k}{ }_{1}(t-t a u)$. Estimates from the model include tau (calculated time until first appearance of marker in feces), $k$ (initial concentration of marker in the compartment) and $k_{1}$ (passage rate constant). Calculations derived from estimates included:

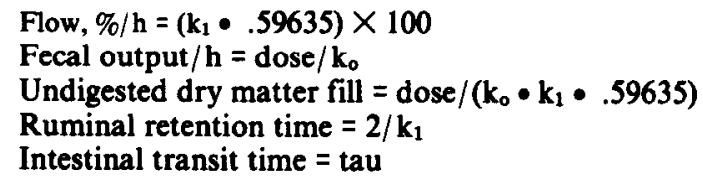

Organic matter intake (OMI) was calculated as the ratio of fecal OM output to $O M$ indigestibility, where fecal output was estimated from $\mathrm{Yb}$ and $\mathrm{OM}$ indigestibility was derived from 2-stage in vitro digestion.

Because of restrictions in facilities, animals, and nature of the long-term study, it was not possible to replicate fertilized and unfertilized pastures. In effect, steers within pasture served as psuedo-replicates, and pasture and fertilizer treatment were confounded. Because of the limited number of esophageal-fistulated steers used in the study, no statistical analyses were conducted on botanical or chemical composition data. The botanical and nutritional information is provided to enhance interpretation of ruminal fermentation, intake, and digesta kinetics data.

Intake and digesta passage data were analyzed as a split-plot design by year after fertilization or year of fertilization with effects for main-plot treatment (fertilization), steer within main-plot, subplot (trial), and trial $\times$ treatment in the model. Main-plot effects were tested by steer within treatment, and subplot effects were tested with residual error. Significant trial $X$ treatment interactions $(P<.05)$ were observed; therefore, comparisons were made within trial. Fermentation measurements were analyzed by an analysis of variance as a split-plot design with effects of steer, treatment, sampling time, sampling time $X$ treatment and steer within treatment included in the model. No sampling time $X$ treatment interaction was noted for fermentation measurements, thus values were pooled over time. Means were separated by the treatment F-test (Cochran and Cox 1968). Correlations were computed with the correlation procedure of SAS (1984).

\section{Results and Discussion}

\section{Botanical and Nutrient Composition of Diets}

During active growing periods for warm-season grasses (June-September), grass consumption averaged $67 \%$ (Table 1). As grasses approached dormancy (October-May), grass consumption decreased to $53 \%$, while dietary forb intake increased from 33 to $47 \%$. Blue grama, sand dropseed, and muhlenbergia species were the primary grasses consumed during the study by steers in both treatment groups. Major forbs consumed were carruth sagewort, scarlet globemallow, and kochia. Kochia consumption was restricted to the growing season, while carruth sagewort utilization occurred primarily during winter dormancy.

Dietary similarities of steers grazing fertilized and nonfertilized pastures were $61 \%$ (EAUG83), 73\% (LAUG83), 61\% (ENOV83), 67\% (EJAN84), 90\% (MAY84), 81\% (LJUL84), 80\% (LAUG84), and $87 \%$ (LNOV84). The low dietary similarities observed during this study indicate fertilization resulted in dietary shifts in animal selectivity or species availability. These dietary differences between pastures subsequently influenced ruminal fermentation, intake, and digesta kinetic data.

Organic matter $(\mathrm{OM})$ percentage of diets did not vary between fertilized and nonfertilized pasture during the year of or year after fertilization (Table 1). These values are consistent with previous studies on fertilized (Cordova 1978, Wallace et al. 1983) and nonfertilized (Thetford et al. 1971, Wallace et al. 1983, Judkins et al. 1985, McCollum et al. 1985) pastures at Fort Stanton, but are lower than those reported from other studies in the western United States (Conner et al. 1963).

Dietary ADF and NDF were not affected by treatment (Table 1). Normally, advancing maturity is associated with increasing fiber constituents (Ulyatt 1981, Van Soest 1982). However, NDF tended to decline with advancing season, during the present study, especially during the year of fertilization, which may reflect selective grazing by the steers. As previously stated, forb consumption increased with advancing season and could explain the decline in NDF. Similar declines in content of fiber constituents were observed by McCollum et al. (1985) for steers grazing comparable nonfertilized blue grama rangeland.

Dietary crude protein levels were numerically higher in the fertilized pasture than in the nonfertilized pasture for each trial (Table 1). In all trials except EJAN84 (nonfertilized pasture) and LNOV84 (both pastures), dietary crude protein was adequate 
(assuming adequate forage consumption) for growing heifers and steers (minimum wt $225 \mathrm{~kg}$ ) gaining $0.5 \mathrm{~kg} /$ day (9.5-10\%), lactating cows (9-10\%), and heifers (9-11\%; NRC 1984). Crude protein levels were, however, sufficient for pregnant cows (7-8\%) and yearling heifers (8-9\%) during EJAN84 and LNOV84. Crude protein levels declined appreciably with advancing forage maturity.

Generally, as season advanced extent of IVOMD declined (Table 1). Similar trends in digestibility have been reported for nonfertilized (Karn and Lorenz 1983, McCollum et al. 1985) and fertilized (Cordova 1978, Havstad et al. 1979) blue grama rangeland. In contrast, Thetford et al. (1971) did not observe a seasonal decline in IVOMD for either sheep or cattle grazing nonfertilized blue grama rangeland.

Phenolics in excess of $20 \mathrm{mg} / \mathrm{g}$ of dry matter can depress nutritive value of forages by reducing voluntary feed intake and decreasing fiber and protein digestibility (Mcleod 1974, Robbins 1983, Barry and Reid 1985). Proposed causes of reduced forage intake include decreased palatability (Wilkins et al. 1953, Donnelly 1954) and decreased ruminal and intestinal permeability, which could interfere with nutrient absorption (Mitjavila et al. 1979; as cited by McLeod 1974, Barry and Forss 1983). Decreased fiber and protein digestibility have been attributed to inhibition of microbial cellulolysis and pectinolysis (McLeod 1974, Van Soest 1982, Robbins 1983, Hahn et al. 1984, Barry and Reid 1985). Plants containing high amounts of tannins have often been found relatively resistant to degradation in the rumen. Tannins have strong protein-binding properties and may complex with other nutrients and metabolic intermediates (Jung and Fahey 1983). Other workers have suggested rumen microorganisms can readily adapt to phenolic and tannin exposure and alleviate negative effects of these secondary compounds (Van Soest 1982, Robbins 1983, Barry and Reid 1985).

Results of this study indicate cattle grazing blue grama rangeland did not consume phenolic or tannin compounds in quantities sufficient to markedly alter forage intake or digestibility (Table 1). However, during certain times of the year, consumption of plant species with high phenolic or tannin content could alter fermentation and digestion of protein and fiber. Further evaluation of effects of phenolic compounds on OMI and digestive physiology of grazing ruminants is needed.

\section{Ruminal Fermentation Measurements}

Ruminal pH ranged from 5.9 to 6.5 during the study (Table 2). This range is similar to results of McCollum et al. (1985;6.1 to 6.8) for steers grazing a nonfertilized pasture at Fort Stanton the year before the present study. Under grazing conditions, ruminal $\mathrm{pH}$ normally varies from 6.3 to 7.0 , because of time spent grazing and ruminating in relation to ruminal VFA production (Qrskov 1982). Mertens (1979) suggested fiber digestion is diminished at a $\mathbf{p H}$ lower than 6.7. Similarly, Qrskov (1982) reported pH lower than 6.2 inhibits growth of cellulolytic bacteria. Ruminal $\mathrm{pH}$ was higher $(P<0.05)$ in the fertilized pasture for LAUG83, ENOV83, and
LAUG84 trials, while differences $(P>0.05)$ were observed in other trials (Table 2).

Variation in pH was low across trials. Declining diet quality with advancing season did not result in an increase in ruminal pH, which would be expected if a smaller quantity of VFA were buffered by more saliva associated with increased chewing time and rumination of dormant forages. Results of this study differ from previous work of McCollum et al. (1985) in which ruminal pH increased with advancing season for steers grazing nonfertilized blue grama rangeland.

Molar proportions of individual acids varied with plant maturity with acetate increasing with advancing season (Table 2). This would be expected, because acetate is reflective of cell wall fermentation (Van Soest 1982). Butyrate tended to decline with advancing season (Table 2). Similar shifts in molar proportions of VFA between wet versus dry and growing versus dormant seasons have been observed in grazing ruminants (Topps et al. 1965, Langlands and Sanson 1976, Playne and Kennedy 1976, McCollum et al. 1985). Minor acids (isobutyrate, valerate, isovalerate) varied seasonally, with highest proportions occurring during the growing season and lowest proportions with forage dormancy (Table 2). These minor acids are required by many cellulolytic species in the rumen (Orskov 1982) and may partially explain the concurrent decline in extent of IVOMD noted in the present study.

Fertilization decreased $(P<0.05)$ acetate proportions only during LAUG83 (Table 2). However, fertilization increased $(P<0.05)$ minor acid proportions during all trials except ENOV83 and MAY84 when no difference $(P>0.05)$ was observed and LNOV84 when ruminal fluid from steers grazing nonfertilized pasture contained a higher $(P<0.05)$ proportion of minor acids. Propionate and butyrate levels did not differ $(P>0.05)$ between fertilized and nonfertilized pasture (Table 2).

Ruminal ammonia $\left(\mathrm{NH}_{3}\right)$ was increased $(P<0.05)$ by fertilization within each sampling period except LNOV84 (Table 2). Seasonally, highest $\mathrm{NH}_{3}$ concentrations coincided with active growing seasons and high dietary $\mathbf{N}$ content, while lowest $\mathrm{NH}_{3}$ concentrations were observed during dormancy when dietary $\mathbf{N}$ and IVOMD were lowest (Table 2). Playne and Kennedy (1976) detected a similar relationship between season of year and dietary $\mathbf{N}$ content. Satter and Slyter (1974), working in vitro, and Roffler et al. (1976), working in vivo, suggested a minimum ruminal $\mathrm{NH}_{3}$ concentration of $5 \mathrm{mg} / 100 \mathrm{ml}$ of rumen fluid is required for optimal microbial protein synthesis. However, Slyter et al. (1979) puts a minimum ammonia concentration of $2.2 \mathrm{mg} / 100 \mathrm{ml}$ of rumen fluid for optimum microbial protein synthesis. Fifty to $70 \%$ of ruminal microbial $\mathbf{N}$ is derived from ammonia $\mathbf{N}$ (Hespell 1979). Ruminal $\mathrm{NH}_{3}$ levels in cattle grazing fertilized pasture were above $5 \mathrm{mg} / 100$ ml throughout the study, indicating microbial protein synthesis and flow to the small intestine were probably not limited by $\mathrm{NH}_{3}$ supply. However, ruminal $\mathrm{NH}_{3}-\mathrm{N}$ levels in the fertilized pasture

Table 4. Particulate pasage rate and retention time for steers graxing fertilized (F) and nonfertilized (NF) blue grama rangeland during the year of and year after fertilization.

\begin{tabular}{|c|c|c|c|c|c|c|c|c|c|c|c|c|c|c|c|c|c|c|c|c|c|c|c|c|}
\hline \multirow[b]{3}{*}{ Item } & \multicolumn{15}{|c|}{ Sampling periods (year after fertilization) } & \multicolumn{9}{|c|}{ Sampling periods (year of fertilization) } \\
\hline & \multicolumn{3}{|c|}{$\begin{array}{c}\text { Early August } \\
1983 \\
\end{array}$} & \multicolumn{3}{|c|}{$\begin{array}{c}\text { Late August } \\
1983 \\
\end{array}$} & \multicolumn{3}{|c|}{$\begin{array}{l}\text { Early November } \\
1983 \\
\end{array}$} & \multicolumn{3}{|c|}{$\begin{array}{c}\text { Early January } \\
1984\end{array}$} & \multicolumn{3}{|c|}{$\begin{array}{l}\text { May } \\
1984\end{array}$} & \multicolumn{3}{|c|}{$\begin{array}{l}\text { Late July } \\
1984 \\
\end{array}$} & \multicolumn{3}{|c|}{$\begin{array}{c}\text { Late August } \\
1984 \\
\end{array}$} & \multicolumn{3}{|c|}{$\begin{array}{c}\begin{array}{c}\text { Late November } \\
1984\end{array} \\
\end{array}$} \\
\hline & $\mathbf{F}$ & NF & $\mathrm{SE}^{\mathbf{2}}$ & $\mathbf{F}$ & NF & $\overline{\text { SE }}$ & $\mathbf{F}$ & NF & $\overline{\text { SE }}$ & $\mathbf{F}$ & NF & $\overline{\text { SE }}$ & $\mathbf{F}$ & NF & SE & $\mathbf{F}$ & NF & $\overline{\text { SE }}$ & F & NF & $\overline{\mathrm{SE}}$ & $\mathbf{F}$ & NF & $\overline{S E}$ \\
\hline $\begin{array}{l}\text { Particulate } \\
\text { passage } \\
\text { rate, } \% / \text { h }\end{array}$ & $5.1^{\mathrm{b}}$ & $3.8^{\mathrm{e}}$ & 0.4 & $5.1^{\mathrm{b}}$ & $3.5^{\mathrm{c}}$ & 0.4 & 3.7 & 3.9 & 0.1 & $3.4^{\mathrm{b}}$ & $2.7^{c}$ & 0.2 & 4.5 & 4.0 & 0.3 & $3.6^{\mathrm{b}}$ & $3.2^{\mathrm{c}}$ & 0.1 & $4.5^{b}$ & $3.3^{\mathrm{c}}$ & 0.3 & 3.1 & 3.0 & 0.3 \\
\hline $\begin{array}{l}\text { Ruminal } \\
\text { retention } \\
\text { time, h } \\
\text { Intestinal } \\
\text { transit } \\
\text { time, } h\end{array}$ & $23.6^{\mathrm{b}}$ & $32.9^{c}$ & 3.1 & $23.9^{b}$ & $34.0^{\mathrm{c}}$ & 2.1 & 32.5 & 30.4 & 1.0 & $35.5^{b}$ & $45.9^{c}$ & 3.2 & 26.6 & 30.6 & 1.9 & 33.2 & 36.8 & 1.3 & $26.5^{b}$ & $36.4^{c}$ & 2.2 & 40.5 & 44.0 & 5.1 \\
\hline
\end{tabular}

\footnotetext{
Standard error, $\mathrm{N}=4$
}

be Means within trials with different superscripts differ $(R<.05)$. 
during EJAN84 and LNOV84 were marginally sufficient for microbial protein synthesis (Table 2). On the other hand, cattle grazing nonfertilized pasture had potentially deficient $\mathrm{NH}_{3}$ levels during ENOV83 $(2.2 \mathrm{mg} / 100 \mathrm{ml})$, EJAN84 $(3.2 \mathrm{mg} / 100 \mathrm{ml})$, and LNOV84 $(3.0 \mathrm{mg} / 100 \mathrm{ml})$ when forage was dormant. Similar ruminal $\mathrm{NH}_{3}$ levels have been reported for cattle grazing nonfertilized blue grama rangeland (McCollum et al. 1985, Funk 1986). These results indicate nonfertilized winter pasture may not contain sufficient $\mathbf{N}$ to supply adequate ruminal ammonia levels for optimal microbial growth and metabolism. Biological consequences include decreased rate of ruminal fermentation (Mehrez and Orskov 1976), increased microbial requirements for growth and maintenance as a result of limited substrates for biosynthesis of cellular constituents (Hespell 1979) and a loss of endogenous $\mathbf{N}$ from the body resulting in negative $\mathbf{N}$ balance. Fermentation of resistant feedstuffs can be adversely affected by insufficient $\mathrm{NH}_{3}$ levels (Tamminga 1979). In addition, Qrskov (1982) suggested $N$ requirements for optimum microbial growth are less than requirements for maximum organic matter digestion. Ruminal $\mathrm{NH}_{3}$ concentrations in both pastures in all trials were below the minimum level $>20 \mathrm{mg} / 100 \mathrm{ml}$ ) suggested by $Q$ rskov (1982) for maximum digestion.

\section{Forage Intake}

Voluntary organic matter intake (OMI) was unaffected $(P>0.05)$ by fertilization during any sampling periods except in EJAN84 when intake was greater $(P<0.05)$ for steers grazing fertilized than for those grazing nonfertilized pasture and LNOV84 when intake was greater $(P<0.05)$ for steers grazing nonfertilized pasture (Table 3). These conflicting results may be caused by the larger difference in forage digestibility between pastures in LNOV84 compared with EJAN84 (Table 1). Numerous studies have shown fertilization with various levels of $\mathrm{N}$ did not influence forage intake by grazing sheep (Mahoney and Poulton 1962, Holmes and Lange 1963, Reid and Jung 1965, Reid et al. 1966) or cattle (Cordova 1978). However, Odhuda et al. (1965) and Kelsey et al. (1973) noted significant increases in intake for sheep consuming $\mathbf{N}$ fertilized forages. Minson (1973) reported a 78\% increase in forage intake of sheep grazing $\mathbf{N}$-fertilized tropical pasture. In the present study, organic matter intake by steers averaged $21.8 \mathrm{~g} \mathrm{OM} / \mathrm{kg} \mathrm{BW}$ and $21.6 \mathrm{~g} \mathrm{OM} / \mathrm{kg} \mathrm{BW}$ across the 8 trials for the fertilized and nonfertilized pastures, respectively. Cordova (1978) reported average yearlong intake levels for steers grazing fertilized and nonfertilized blue grama rangeland of $16.6 \mathrm{~g} \mathrm{OM} / \mathrm{kg} \mathrm{BW}$ and $18.0 \mathrm{~g} \mathrm{OM} / \mathrm{kg} \mathrm{BW}$, respectively. Similarly, McCollum (1983) reported average yearlong intake levels of $18.5 \mathrm{~g} \mathrm{OM} / \mathrm{kg} \mathrm{BW}$ for steers grazing nonfertilized blue grama rangeland. Rosiere et al. (1980) reported intake estimates for lactating and nonlactating 2-yr-old cows grazing blue grama rangeland during the summer of $21.0 \mathrm{~g} \mathrm{OM} / \mathrm{kg} \mathrm{BW}$ and $14.0 \mathrm{~g} \mathrm{OM} / \mathrm{kg} \mathrm{BW}$, respectively.

In the present study, intake declined with advancing season, which is consistent with earlier studies on blue grama rangeland in New Mexico (Cordova 1978, McCollum and Galyean 1985b) and Nebraska sandhills (Powell et al. 1982). Steers grazing the fertilized pasture during the year after fertilization experienced an OMI decline of $16 \%$ from the EAUG83 and LAUG83 to ENOV83 and EJAN84 sampling periods, while a decrease of $22 \%$ was observed in the nonfertilized pasture over the same time period. In contrast, during the year of fertilization, OMI declined $33 \%$ fertilized pasture from MAY84 through LNOV84, while only a 5\% decrease was observed in nonfertilized pasture for the same period.

Neutral detergent fiber intake (NDFI) estimates were variable with no consistent trends noted between fertilized and nonfertilized pastures during the year of or year after fertilization (Table 3). Neutral detergent fiber intake declined with advancing season, as would be expected with the observed decline in OMI and decrease in dietary NDF. Previous forage studies suggest cell wall content limits intake when proportion of cell wall exceeds 50 to $60 \%$ of the dry matter (Van Soest 1965). Diet samples collected during this study contained in excess of $60 \%$ NDF and NDFI declined with advancing season within each pasture supporting the concept that NDF is a major factor limiting forage intake.

Fecal output (FO) varied from a low of 5.6 to a high of $12.4 \mathrm{~g} / \mathrm{kg}$ BW across all sampling trials and treatments (Table 3). Kahn and Spedding (1984) and McCollum and Galyean (1985b) reported a similar range of FO estimates for cattle grazing rangeland. The variation in FO observed during this study could be the result of a combination of expanded gut capacity and botanical components consumed during these sampling periods. Freer (1981) and Kahn and Spedding (1984) postulated gut capacity would increase in response to prolonged consumption of low-quality forage in order to maintain the same intake of metabolizable energy, but only up to a point associated with critical distension of the alimentary tract during eating. Examination of data revealed that generally when gut fill was greatest (Table 3 ), steer diets contained predominantly grasses (Table 1). The ease and manner in which forb material fragments during comminution might enable digesta to pack more densely in the gastrointestinal tract and allow for increased fill with high-forb diets (Ingalls et al. 1966, Troelson and Campbell 1968). However, during the present study, gut fill estimates were generally lowest during sampling periods when steers consumed high-forb diets. The rate of digestion of forbs which is generally faster than other forage components may compensate for the packing density effect and result in minimal change in gut fill estimates.

Table 5. Ruminal fluid passage rate, volume and turnover rate and time for steers grazing fertilized (F) and nonfertilized (NF) blue grama rangeland during the year of and year after fertilization.

\begin{tabular}{|c|c|c|c|c|c|c|c|c|c|c|c|c|c|c|c|c|c|c|c|c|c|c|c|c|}
\hline \multirow[b]{3}{*}{ Item } & \multicolumn{15}{|c|}{ Sampling periods (year after fertilization) } & \multicolumn{9}{|c|}{ Sampling periods (year of fertilization) } \\
\hline & \multicolumn{3}{|c|}{$\begin{array}{c}\text { Early August } \\
1983\end{array}$} & \multicolumn{3}{|c|}{$\begin{array}{c}\text { Late August } \\
1983\end{array}$} & \multicolumn{3}{|c|}{$\begin{array}{c}\text { Early November } \\
1983\end{array}$} & \multicolumn{3}{|c|}{$\begin{array}{c}\text { Early January } \\
1984\end{array}$} & \multicolumn{3}{|c|}{$\begin{array}{l}\text { May } \\
1984\end{array}$} & \multicolumn{3}{|c|}{$\begin{array}{c}\text { Late July } \\
1984\end{array}$} & \multicolumn{3}{|c|}{$\begin{array}{c}\text { Late August } \\
1984\end{array}$} & \multicolumn{3}{|c|}{$\begin{array}{c}\text { Late November } \\
1984\end{array}$} \\
\hline & $\mathbf{F}$ & NF & SE & $\mathbf{F}$ & NF & SE & $\mathbf{F}$ & NF & SE & $\mathbf{F}$ & NF & SE & $\mathbf{F}$ & NF & SE & $\mathbf{F}$ & NF & $\mathbf{S E}$ & $\mathbf{F}$ & NF & $\overline{\text { SE }}$ & F & NF & SE \\
\hline $\begin{array}{l}\text { Fluid } \\
\text { passage } \\
\text { rate, } \% / \text { h }\end{array}$ & 10.6 & 11.8 & 1.0 & 11.2 & 9.1 & 1.3 & 10.5 & 8.6 & 0.8 & 8.1 & 7.2 & 1.0 & 11.5 & 11.1 & 0.5 & 9.9 & 10.9 & 0.9 & $9.8^{\mathrm{b}}$ & $11.3^{\mathrm{c}}$ & 0.4 & 10.8 & 8.9 & 0.8 \\
\hline $\begin{array}{l}\text { Fluid } \\
\text { volume, } \\
\text { liters/kg } \\
\text { BW }\end{array}$ & 0.1 & 0.1 & 0.1 & 0.1 & 0.2 & 0.1 & 0.2 & 0.2 & 0.1 & 0.2 & 0.2 & 0.1 & 0.2 & 0.2 & 0.1 & 0.2 & 0.2 & 0.1 & 0.2 & 0.2 & 0.1 & 0.1 & 0.1 & .0 \\
\hline $\begin{array}{l}\text { Fluid turn } \\
\text { over rate, } \\
\text { liters / h }\end{array}$ & 3.6 & 5.7 & 0.8 & 5.8 & 6.2 & 1.1 & 6.4 & 6.2 & 1.0 & 7.7 & 5.3 & 2.8 & 9.8 & 10.7 & 0.4 & 8.9 & 9.4 & 0.7 & $9.7^{b}$ & $9.2^{\mathrm{c}}$ & 0.3 & $4.4^{b}$ & $6.6^{c}$ & 1.1 \\
\hline $\begin{array}{l}\text { Fluid } \\
\text { turnover } \\
\text { time, h }\end{array}$ & 9.4 & 8.5 & 1.4 & 8.9 & 11.0 & 1.7 & 9.5 & 11.6 & 0.7 & 12.3 & 13.9 & 0.5 & 8.7 & 9.1 & 0.6 & 10.1 & 9.2 & 0.8 & 10.2 & 8.8 & 0.5 & 9.3 & 11.2 & 0.5 \\
\hline
\end{tabular}

'Standard error, $n=4$.

${ }^{\circ}$ Means witin trials with different superscripts differ $(P<.05)$ 


\section{Pasange Rate Estimates}

Particulate passage rate (PPR) was faster in steers grazing fertilized pasture during LAUG83 $(P<0.05)$, EJAN84 $(P<0.05)$, and LAUG84 $(P<0.05)$ than in steers grazing nonfertilized pasture. However, no differences $(P>0.05)$ were noted in PPR during the remaining sampling periods (Table 4). In general, PPR declined in both fertilized and nonfertilized pastures with advancing season, which would be expected because there was a concurrent increase in undigested residues in the gut which was reflected in increased gut fill (Table 3) and lower organic matter digestion with advancing season (Table 1). Increased PPR was associated with decreased ruminal retention time (RRT) and intestinal transit time (ITT). Rumen retention time was decreased $(P<0.05)$ in steers grazing fertilized compared with nonfertilized pasture during the year after fertilization for the EAUG83, LAUG83, and EJAN84 trials. Similarly, during the year of fertilization, steers grazing fertilized rangeland had decreased ( $P<0.05)$ RRT and LAUG84 compared with steers grazing nonfertilized rangeland (Table 4). Ruminal retention time averaged $30.7 \mathrm{~h}$ and $35.9 \mathrm{~h}$ across the 8 trials for the fertilized and nonfertilized pastures, respectively. McCollum (1983) reported similar RRT ( $34.3 \mathrm{~h}$ ) for cattle grazing nonfertilized blue grama rangeland. Likewise average ITT for the present study was faster for steers grazing fertilized $(14.1 \mathrm{~h})$ versus nonfertilized $(17.6 \mathrm{~h})$ pastures. Intestinal transit time was lower $(P<0.05)$ in steers grazing fertilized compared with nonfertilized rangeland during LAUG83, ENOV83 and EJAN84 (Table 4). No differences $(P>0.05)$ were noted for other trials.

Organic matter intake in the fertilized pasture across both years showed a negative relationship with $\operatorname{RRT}(r=-.51, P<0.05)$ and ITT $(r=-.58, P<0.05)$. Likewise, OMI in the nonfertilized pasture across years showed a negative relationship with RRT $(r=-.50$, $P<0.05)$ and ITT $(r=-.38, P<0.05)$. In addition, dry matter fill was negatively correlated to PPR for both fertilized $(r=-.68, P<0.10)$ and nonfertilized $(r=-.37, P<0.05)$ pastures. These data indicate declines in OMI with advancing season are associated with dietary factors, slower PPR and increased gastrointestinal dry matter fill.

Fluid passage rate (FPR) and fluid turnover time were unaffected $(P>0.05)$ by fertilization except during the LAUG84 period when FPR was faster $(P<.05)$ in steers grazing fertilized versus nonfertilized pasture (Table 5). During the year after fertilization, no differences $(P>0.05)$ were noted in fluid volume and turnover rate, but some minor differences were observed during the year of fertilization (Table 5). The FPR observed in the present study were typical for ruminants consuming forage diets (Kennedy 1982 , McCollum and Galyean 1985b).

Research conducted by McCollum and Galyean (1985b) showed a high correlation $(P<0.05)$ of FPR with OMI $(r=.65)$ and PPR $(r$ $=.77$ ) for steers grazing nonfertilized blue grama rangeland. During the present study, however, these relationships were less pronounced for steers grazing nonfertilized pasture (FPR with OMI; $r$ $=.34, P<0.10 ;$ FPR with PPR; $r=.40, P<0.05)$. Goetsch and Owens (1985) proposed faster FPR would increase removal of small particles, thereby increasing PPR. In contrast, no significant relationship $(P>.50)$ was observed among FPR, OMI, and PPR in the fertilized pasture. Results from the fertilized pasture support the findings of Varga and Prigge (1982) in which a 2-fold increase in FPR did not influence PPR.

As noted with RRT, advancing season was accompanied by longer fluid turnover times. McCollum and Galyean (1985b) reported a constant relationship between the flow of fluid and particulate matter through the GIT for steers grazing nonfertilized blue grama rangeland. The ratio of fluid turnover time to RRT was $.41, .41, .30, .35, .33, .30, .38, .21$ for EAUG83, LAUG83, ENOV83, EJAN84, MAY84, LAUG84, and LNOV84, respectively, for the fertilized pasture and $.26, .32, .40, .35, .30, .26, .24$, .29 for EAUG83, LAUG83, ENOV83, EJAN84, MAY84, LJUL84, LAUG84, and LNOV84, respectively, for nonfertilized pasture. These data, while not statistically evaluated, suggest differ factors affect flow of fluids and particulates, and their relationship to each other is minimal.

Fertilization altered steer selectivity, with steers grazing fertilized rangeland consuming a higher percentage of forbs than steers grazing nonfertilized rangeland. Correspondingly, total available $\mathbf{N}$ content was higher and fiber constituents were generally lower for diets consumed by steers grazing fertilized blue grama rangeland. However, during the year of fertilization, fiber constituents were generally higher for diets consumed by steers grazing fertilized as compared with those grazing nonfertilized rangeland. Similarly, fertilization increased digestiblity during the growing season but digestibility was depressed by fertilization during dormancy. Results from this study indicate steers grazing $\mathbf{N}$ fertilized rangeland had increased ruminal $\mathrm{pH}$ and $\mathrm{NH}_{3}$ levels throughout the year, but fertilization had little effect on VFA proportions when compared with nonfertilized rangeland.

Nitrogen fertilization (year after application) of blue grama rangeland had a minimal effect on voluntary forage intake. However, fertilization generally increased forage digestion and PPR. Correspondingly, RRT and ITT were reduced in steers grazing fertilized blue grama rangeland. During the year of $\mathbf{N}$ fertilization, voluntary forage intake was increased during growing season but was depressed during dormancy. Fertilization generally increased PPR and decreased RRT and ITT.

\section{Literature Cited}

AOAC. 1984. Official methods of analysis (14th ed.). Association of Official Analytical Chemists. Washington, D.C.

Banner, R.E. 1969.Influence of nitrogen fertilization on production characteristics of blue grama. M.S. Thesis. New Mexico State Univ., Las Cruces.

Barry, T.N., and D.A. Forss. 1983. The condensed tannin content of vegetative Lotus pedunculatus, its regulation by fertilizer application, and effect upon protein solubility. J. Sci. Food Agr. 34:1047-1056.

Barry, T.N., and C.S.W. Reid. 1985. Nutritional effects attributable to condensed tannins, cyanogenic glycosides and oestrogenic compounds in New Zealand forages. p. 251-259. In: R.F. Barnes, P.R. Ball, R.W. Brougham, G.C. Marten, and D.J. Minson (eds.). Forage Legumes for Energy-Efficient Animal Production. Proc. Trilateral Workshop. USDAARS.

Broderick, G.A., and J.H. Kang. 1980. Automated simultaneous determinations of ammonia and total amino acids in ruminal fluid and in vitro media. J. Dairy Sci. 33:64-75.

Burns, R.E. 1971. Method for estimation of tannin in grain sorghum. Agron. J. 63:511-512.

Burzlaff, D.F., G.W. Flock, and L.R. Rittenhouse. 1968. Effect of nitrogen fertilization on certain factors of a western Nebraska range ecosystem. J. Range Manage. 21:21-24.

Cochran, W.G., and G.M. Cox. 1968. Experimental designs (2nd ed.). John Wiley \& Sons, Inc., New York.

Conner, J.M., V.R. Bohman, A.L. Lesperance, and F.E. Kinsinger. 1963. Nutritive evaluation of summer range forage with cattle. J. Anim. Sci. 22:961-969.

Cook, C.W. 1972. Comparative nutritive values of forbs, grasses and shrubs. p. 303-310. In: C.M. McKell, J.P. Blaisdell and J.R. Goodin (eds.). Wildland Shrubs-Their Biology and Utilization. USDA Forest Serv. Gen. Tech. Rep. INT-1.

Cordova, F.J. 1978. Intake and nutritive value of forage grazed by cattle on fertilized and unfertilized blue grama rangeland. Ph.D. Diss. New Mexico State Univ. Univ Microfilms. Ann Arbor, Mich.

Cordova, F.J., J.D. Wallace, and R.D. Pieper. 1983. Forage intake by grazing livestock: A review. J. Range Manage. 31:430-438.

Donart, G.B., E.E. Parker, and R.D. Pieper. 1983. Livestock and rangeland performance to nitrogen fertilization in southcentral New Mexico. p. 351-354. In: D.B. Hannaway (ed.). Foothills and Food and Forests, Symposium No. 2. Timber Press, Beaverton, Ore.

Donart, G.B., E.E. Parker, R.D. Pieper, and J.D. Wallace. 1978. Nitrogen fertilization and livestock grazing on blue grama rangeland. Proc. Int. Rangeland Cong. 1:614-615.

Donnelly, E.D. 1954. Some factors that affect palatability in sericea lespedeza (L. cuneata). Agron. J. 46:96.

Ellis, W.C. 1978. Determinants of grazed forage intake and digestibility. J. Dairy Sci. 61:1828-1840. 
Freer, M. 1981. The control of food intake in grazing animals. p. 105-124. In: F.H. Morley (ed.). Grazing Animals. Elsevier Sci. Publ. Co., New York.

Funk, M.A. 1986. Effect of changes in forage quality throughout the growing season on dietary composition, intake, digestion and microbial protein synthesis in steers grazing blue grama rangeland. M.S. Thesis. New Mexico State Univ., Las Cruces.

Goering, H.D., and P.J. Van Soest. 1970. Forage fiber analyses (apparatus, reagents, procedures and some applications). USDA-ARS Handbook No. 379.

Goetsch, A.L., and M.L. Galyean. 1983.Influence of feeding frequency on passage of fluid and particulate markers in steers fed a concentrate diet. Can. J. Anim. Sci. 63:727-730.

Goetsch, A.L., and F.N. Owens. 1985. Effects of sampling site on passage rate estimates in heifers fed alfalfa hay or a high concentrate diet. J. Dairy Sci. 68:914-922.

Goetz, H. 1969. Composition and yields of native grassland sites fertilized at different rates of nitrogen. J. Range Manage. 22:384-390.

Hahn, D.H., L.W. Rooney, and C.F. Earp. 1984. Tannins and phenols of sorghum. Cereal Foods World 29:776-779.

Havstad, K.M., R.D. Pieper, G.B. Donart, J.D. Wallace, F.J. Cordova, and E.E. Parker. 1979. Cattle diets on a fertilized blue grama upland range site. J. Range Manage. 32:398-401.

Hespell, R.B. 1979. Efficiency of growth by ruminal bacteria. Fed. Proc. 38:2707-2716.

Holechek, J.L., and M.Vavra. 1982. Forage intake by cattle on forest and grassland ranges. J. Range Manage. 35:737-741.

Holmes, J.C., and R.W. Lange. 1963. Effects of fertilizer nitrogen and herbage dry matter content on herbage intake and digestibility in bullocks. Anim. Prod. 5:17-26.

Humphrey, R.R. 1960. Range ecology. Ronald Press Co. New York.

Ingalis, J.R., J.W. Thomas, M.B. Tear, and D.L. Carpenter. 1966. Relations between ad libitum intake of several forage species and gut fill. $J$. Anim. Sci. 25:283-289.

Jung, H.G., and G.C. Fabey. 1983. Nutritional implications of phenolic monomers and lignin: A review. J. Anim. Sci. 57:206-219.

Judkins, M.B., L.J. Kryal, J.D. Wallace, M.L. Galyean, K.D. Jones, and E.E. Parker. 1985. Intake and diet selection by protein supplemented grazing steers. J. Range Manage. 38:210-214.

Karn, J.F., and R.J. Lorenz. 1983. Supplementation of yearling steers grazing fertilized and unfertilized Northern Plains rangeland. J. Range Manage. 36:41-45.

Kahn, H.E., and C.R.W. Spedding. 1984. A dynamic model for simulation of cattle herd production systems: 2- An investigation of various factors influencing the voluntary intake of dry matter and the use of the model in their validation. Agr. Sys. 13:63-82.

Kelsey, R.J., A.B. Nelson, G.S. Smith, and R.D. Pieper. 1973. Nutritive value of hay from nitrogen-fertilized blue grama rangeland. J. Range Manage. 26:292-294.

Kelsey, R.J., A.B. Nelson, G.S. Smith, R.D. Pieper, and J.D. Wallace. 1972. Effects of N-fertilization on blue grama parts. Proc. West. Sec. Amer. Soc. Anim. Sci. 23:237-240.

Kennedy, P.M. 1982. Ruminal and intestinal digestion in Brahman crossbred and Hereford cattle fed alfalfa or tropical pasture hay. J. Anim. Sci. 55:1190-1199.

Kothmann, M.M. 1980. Nutrition of livestock grazing on range and pasture lands. p. 56-90. In: D.C. Church (ed.). Digestive Physiology and Nutrition of Ruminants Vol. 3. Practical Nutrition. (2nd ed.). $O$ and $B$ Books, Corvallis, Ore.

Langlands, J.P., and J. Sanson. 1976. Factors affecting the nutritive value of the diet and the composition of rumen fluid of grazing sheep and cattle. Australian J. Agr. Res. 27:691-708.

Lebgue, T., and K.W. Allred. 1985. Flora of the Fort Stanton Experimental Ranch, Lincoln, County, New Mexico. New Mexico Agr. Exp. Sta. Bull. 557.

Mahoney, A.W., and B.R. Poulton. 1962. Effects of nitrogen fertilization and date of harvest on the acceptability of timothy forage. J. Dairy Sci. 45:1575-1581.

McCollum, F.T. 1983. The influence of advancing season on nutritive quality, intake and rumen fermentation of cattle diets on blue grama rangeland. Ph.D. Diss. New Mexico State Univ., Univ. Microfilms. Ann Arbor, Mich.

McCollum, F.T., and M.L. Galyean. 1985.. Influence of cottonseed meal supplementation on voluntary intake, rumen fermentation and rate of passage of prairie hay in beef steers. J. Anim. Sci. 60:570-577.
MeCollum, F.T., and M.L. Galyean. 1985b. Cattle grazing blue grama rangeland II. Seasonal forage intake and digesta kinetics. J. Range Manage. 38:543-546.

McCollum, F.T., M.L. Galyean, L.J. Krysl, and J.D. Wallace. 1985. Cattle grazing blue grama rangeland. I. Seasonal diets and rumen fermentation. J. Range Manage. 38:539-543.

MeLeod, N.M. 1974. Plant tannins-their role in forage quality. Nutr. Abstr. Rev. 44:803-815.

Mehrez, A.Z., and E.R. Orakov. 1976. Rates of rumen fermentation in relation to ammonia concentration. Proc. Nutr. Soc. 35:40A.

Mertens, D.R. 1979. Effects of buffers upon fiber digestion, p. 65-80. In: W.H. Hale and P. Meinhardt (eds.). Regulation of Acid Base Balance. Church and Dwight Company, Inc., Piscataway, N.J.

Mertens, D.R., and J.R. Loften. 1980. The effects of starch on forage fiber digestion kinetics in vitro. J. Dairy Sci. 63:1437-1446.

Minson, D.J. 1973. Effects of fertilizer nitrogen on digestibility and voluntary intake of Chloris gayana, Digitaria decumbens and Pennisetum clandestinum. Australian J. Exp. Agr. Anim. Husb. 13:153-157.

NRC. 1984. Nutrient requirements of domestic animals. No. 4. Nutrient Requirements of Beef Cattle (6th ed). Nat. Acad. Sci. Nat. Res. Counc. Washington, DC.

Odhuda, E.K., R.L. Reid, and G.A. Jung. 1965. Nutritive evaluation of tall fescue pasture. J. Anim. Sci. 24:1216-1221.

Oosting, H.J. 1956. The study of plant communities. W.H. Freeman and Co. San Francisco.

Grakov, E.R. 1982. Protein nutrition in ruminants. Academic Press, New York.

Playne, J.J., and P.M. Kennedy. 1976. Ruminal volatile fatty acids and ammonia in cattle grazing dry tropical pastures. J. Agr. Sci. (Camb.) 86:367-372.

Pieper, R.D., J.R. Montoya, and F.L. Groce. 1971. Site characteristics on pinyon-juniper and blue grama ranges in southcentral New Mexico. New Mexico Agr. Exp. Sta. Bull. 573.

Pieper, R.D., R.J. Kelsey, and A.B. Nelson. 1974. Nutritive quality of nitrogen fertilized and unfertilized blue grama. J. Range Manage. $27: 470-472$.

Pieper, R.D., A.B. Nelson, G.S. Smith, E.E. Parker, E.J.A. Bogpino, and S.F. Hatch. 1978. Chemical composition and digestibility of important range grass species in south central New Mexico, New Mexico State Univ., Agr. Exp. Sta. Bull. 662.

Pond, K.R., W.C. Ellis, H.J. Matis, G.T. Schelling, and L.W. Greene. 1982. Compartmental models for estimating gastrointestinal tract fill, flow and output using pulse dose marker data. J. Anim. Sci. 53(Suppl. 1):452.

Powell, D.J., D.C. Clanton, and J.T. Nichols. 1982. Effects of range condition on the diet and performance of steers grazing native sandhills range in Nebraska. J. Range Manage. 35:96-99.

Price, M.L., S. Van Seoyoc, and L.G. Butler. 1978. A critical evaluation of the vanillin reaction as an assay for tannin in sorghum grain. J. Agr. Food Chem. 26:1214-1218.

Reed, R.L. 1969. Effects of nitrogen fertilization and clipping on production and water usage in blue grama. M.S. Thesis. New Mexico State Univ., Las Cruces.

Reid, R.L., and G.A. Jung. 1965. Influence of fertilizer treatment on the intake, digestibility and palatability of tall fescue hay. J. Anim. Sci. 24:615-625.

Reld, R.L., G.A. Jung, and S.J. Murray. 1966. Nitrogen fertilization in relation to the palatability and nutritive value of orchard grass. J. Anim. Sci. 25:636-645.

Robbins, C.T. 1983. Wildlife Feeding and Nutrition. Academic Press, New York.

Romer, R.E., C.G. Schwab, and L.D. Satter. 1976. Relationship between ruminal ammonia and nonprotein nitrogen utilization by ruminants. III. Influence of intraruminal urea infusion on ruminal ammonia concentration. J. Dairy Sci. 59:80-84.

Rogler, G.A., and R.J. Lorenz. 1965. Nitrogen fertilization of natural grassland in the Northern Plains of the United States. Proc. Inter.Grassl. Cong. 9:1327-1330.

Rosiere, R.E., J.D. Wallace, and R.D. Pleper. 1980. Forage intake in 2-year old cows and heifers grazing blue grama summer range. J. Range Manage. 33:71-73.

SAS. 1984. SAS User's Guide. SAS Institute, Inc., Cary, North Carolina. Satter, L.D., and L.L. Slyter. 1974. Effect of ammonia concentrations on rumen microbial protein production in vitro. Brit. J. Nutr. 32:199-208.

Schickedanz, J.G. 1970. Vegetation and cattle response to nitrogen fertilized rangeland. M.S. Thesis. New Mexico State Univ., Las Cruces. 
Slyter, L.L., L.D. Satter, and D.A. Dinius. 1979. Effect of ruminal ammonia concentration on nitrogen utilization by steers. J. Anim. Sci. 48:906.

Sparks, D.R., and J.C. Malechek. 1968. Estimating percentage dry weights in diets using a microscopic technique. J. Range Manage. 21:264-265.

Tamminga, W. 1979. Protein degradation in the forestomachs of ruminants. J. Anim. Sci. 49:1615-1630.

Teeter, R.G., F.N. Owem, and T.L. Mader. 1984. Ytterbium chloride as a marker for particulate matter in the rumen. J. Anim. Sci. 58:465-473.

Thetford, F.D., R.D. Pleper, and A.B. Neleon. 1971. Botanical composition of cattle and sheep diets on pinyon-juniper grassland ranges. J. Range Manage. 24:425-431.

Thomton, R.F., and D.J. Minson. 1973. The relationship between apparent retention time in the rumen, voluntary intake and apparent digestibility of legume and grass diets in sheep. Australian J. Agr. Res. 24:889-898.

Tilley, J.M.A., and R.A. Terry. 1963. A 2-stage technique for the in vitro digestion of forage crops. J. Brit. Grassl. Soc. 18:104-111.

Topps, J.H., W.C. Reed, and R.C. Elliott. 1965. The effect of season and of supplementary feeding on the rumen contents of African cattle grazing subtropical herbage II. pH values and concentrations and proportions of volatile fatty acids. J. Agr. Sci. (Camb.). 64:397-402.
Troeleon, J.E., and J.B. Campbell. 1968. Voluntary consumption of forage by sheep and its relation to the size and shape of particles in the digestive tract. Anim. Prod. 10:289-294.

Ulyatt, M.J. 1981. The feeding value of temperate pastures. p. 125-142. In: F.H.W. Morley (ed.). Grazing Animals Elsevier Scientific Publishing Co., New York.

Uden, P., D.E. Colueci, and P.J. Van Soest. 1980. Investigation of chromium, cerium and cobalt as markers in digesta rate of passage studies. $J$. Sci. Food Agr. 31:625-632.

Van Soeat, P.J. 1965. Symposium of factors influencing the voluntary intake of herbage by ruminants. Voluntary intake in relation to chemical composition and digestibility. J. Anim. Sci. 24:834-843.

Van Soest, P.J. 1982. Nutritional Ecology of the Ruminant. $O$ and $B$ Books, Corvallis, Ore.

Varga, G.A., and E.C. Prizge. 1982. Influence of forage species and level of intake on ruminal turnover rates. J. Anim. Sci. 55:1498-1504.

Wallace, J.D., F.J. Cordova, G.B. Donart, and R.D. Pieper. 1983. Nutritive value of cattle diets on fertilized and unfertilized blue grama rangeland. Proc. Int. Grassl. Cong. 27:688-690.

Wilkins, H.L., R.P. Bates, P.R. Hemson, I.L. Londhal, and R.E. Davis. 1953. Tannin and palatability in sericea lespedeza ( $L$ cuneata). Agron. J. 45:335.

\section{Does your range library have these?}

35-Year Index, Journal of Range Management, edited by Elbert H. Reid. $\$ 10.00$

Plants That Poison, by E.M Schmutz and L.B. Hamilton. $\$ 9.95$

Trail Boss Cowboy Cookbook, $\$ 13.00$

Range Research: Basic Problems and Techniques, edited by C. Wayne Cook and James Stubbendieck. $\$ 28.00$

Rangeland Plant Physiology, edited by Ronald E. Sosebee. $\$ 14.50$

Special Management Needs of Alpine Ecosystems, edited by Douglas A. Johnson. $\$ 4.50$

Rangeland Hydrology, by F.A. Branson, G.F. Gifford, K.G. Renard, and R.F. Hadley. $\$ 15.00$

All prices quoted are postpaid. Also available are back issues of Journal of Range Management and Rangelands and some proceedings and symposia. Place orders and ask for a complete list of publications available from Society for Range Management, 1839 York St., Denver, Colorado 80206. (303) 355-7070. 